IZA DP No. 6912

Tax Reform in Georgia and the

Size of the Shadow Economy

Karine Torosyan

Randall Filer

October 2012

Forschungsinstitut zur Zukunft der Arbeit Institute for the Study of Labor 


\title{
Tax Reform in Georgia and the Size of the Shadow Economy
}

\author{
Karine Torosyan \\ International School of Economics at TSU \\ Randall Filer \\ CUNY Hunter College \\ and IZA
}
Discussion Paper No. 6912
October 2012

\author{
IZA \\ P.O. Box 7240 \\ 53072 Bonn \\ Germany \\ Phone: +49-228-3894-0 \\ Fax: +49-228-3894-180 \\ E-mail: iza@iza.org
}

Any opinions expressed here are those of the author(s) and not those of IZA. Research published in this series may include views on policy, but the institute itself takes no institutional policy positions. The IZA research network is committed to the IZA Guiding Principles of Research Integrity.

The Institute for the Study of Labor (IZA) in Bonn is a local and virtual international research center and a place of communication between science, politics and business. IZA is an independent nonprofit organization supported by Deutsche Post Foundation. The center is associated with the University of Bonn and offers a stimulating research environment through its international network, workshops and conferences, data service, project support, research visits and doctoral program. IZA engages in (i) original and internationally competitive research in all fields of labor economics, (ii) development of policy concepts, and (iii) dissemination of research results and concepts to the interested public.

IZA Discussion Papers often represent preliminary work and are circulated to encourage discussion. Citation of such a paper should account for its provisional character. A revised version may be available directly from the author. 
IZA Discussion Paper No. 6912

October 2012

\section{ABSTRACT}

\section{Tax Reform in Georgia and the Size of the Shadow Economy}

This paper applies three different methods widely used in the literature to track changes in shadow economic activity in Georgia following a drastic tax reform in 2005. The first method is a currency demand approach based on macro level data. The second and third methods rely on micro data from household surveys. Overall, we find evidence that the amount of income underreporting decreased in the years following the reform. The biggest change is observed for households headed by a farmer, followed by "other" types of households where the head does not report any working status. Employed and self-employed households appear very similar before the tax reform and show minimal adjustment in income reporting in the post-reform period. Results, however, suggest that much of any difference may have come from increased enforcement efforts rather than rate changes.

JEL Classification: E01, H26, J39

Keywords: hidden/shadow economy, tax reform, consumer behavior, transition economy

Corresponding author:

Randall K. Filer

Department of Economics

Hunter College/City University of New York

695 Park Avenue

New York, NY 10021

USA

E-mail: rfiler@hunter.cuny.edu 


\section{Introduction}

The shadow economy (also black, hidden, underground economy), which includes all marketbased legal production of goods and services that are deliberately concealed from public authorities, ${ }^{1}$ is a widespread phenomenon in many countries including the Transition Economies (TEs) that underwent a transformation from state-planned to market economies in recent decades. One might expect that these countries, with developing markets, poor institutional frameworks, lack of rule of law, widespread corruption and other problems, would develop large shadow economies. Indeed, recent evidence suggests that the TEs are characterized by high levels of shadow economic activity (Schneider et al. 2010). The average TE ranked 92nd out of 151 economies studied with an average of $37 \%$ of economic activity unreported. Among TEs, there are countries that are the most highly under-reporting economies in the world. According to Schneider, the size of shadow economic activity in Georgia for the period 1999-2007 was the highest in the sample. Estimates (based on the dynamic multiple indicator/multiple cause method) suggest that Georgia's shadow economic activity in the period under consideration amounted to an average of as much as $68.8 \%$ of the official GDP. Azerbaijan came close at number 149 with $63.3 \%$ unreported, while Armenia did slightly better, ranking 131 st with $48.7 \%$ of economic activity unreported.

Among other factors, tax avoidance is thought to be one of the main determinants of the level of unreported economic activity. Past theoretical work, however, has produced ambiguous conclusions regarding the impact of tax rates and their structure on incentives to hide economic activity. Allingham and Sandmo (1972) and Yitzhaki (1974) assert that a reduction in tax rates may alter penalties for noncompliance and, therefore, cost/benefit calculations such that workers might even conceal a greater share of income. Similar results have been found for tax rates by Pencavel (1979) and tax progressivity by Koskela (1983). Adding decreasing absolute and non-increasing relative risk aversion to such a model, however, implies that increases in either tax rates or progressivity will cause growth in the shadow economy (Trandel and Snow, 1998). Other works showing a positive theoretical relationship between taxes and shadow economic activity include KessIman (1989), Cowell (1985) and Watson (1985).

\footnotetext{
${ }^{1}$ We follow the definition provided by Schneider (2004).
} 
Empirical work on the link between taxes and the size of the shadow economy is also mixed. While some studies (Freidman et al., 2000, for example) find no, or even a negative, relationship between taxes and the size of the shadow economy, the vast majority of studies find that higher average and/or marginal tax rates, as well as greater complexity of the tax system, are associated with an increase in the size of the shadow economy. Examples include Giles and Johnson (2002), Theissen (2001), Cebula (1997), Hill and Kabir (1996), Lacroix and Fortin (1992), Schneider (1986), Gorodnichenko et al., (2009) and Slonimczyk (2011).

This paper provides additional empirical evidence regarding the link between the scale of shadow economic activity and a country's tax system. The analysis examines major change in the tax regime in Georgia at the end of 2004, when the country moved from a complex, progressive system with many types of taxes to a much simpler tax regime with relatively low tax rates and a reduced number of taxes. One of the major components of the reform was adopting a low flat rate of $12 \%$ (the lowest in the region) for the personal income tax. Moving to a flat tax is a commonly suggested method for regularizing the shadow economy (see Keen et al., 2006). In addition to the change in the tax structure, the Georgian government also made a great effort to improve tax enforcement.

Estimating the size and changes in the scale of a shadow economic activity is a challenging task because it is practically impossible to measure directly the extent of shadow activity. One must, therefore, rely on various indirect and less precise ways of assessing its scale. Many indirect methods have been used in the literature. Shneider and Enste (2000) and Schneider (2004) provide a detailed review of these methods and their respective advantages/disadvantages. Since each of the available methods is disadvantaged in one way or another we use several alternative methods to obtain a more robust picture of the scale of shadow economic activity in Georgia. Of course, one could rightly argue that each of these methods might still lead to biased assessment of the level of shadow economic activity. Assuming, however, that the extent of such biases is roughly constant over time in each methodology, we can provide insight into the direction and magnitude of the change in underreporting following the reforms. 


\section{Facts about the Georgian Tax Reform}

Taxation was a major problem for Georgia before 2003. Enforcement of tax collection was difficult due to the lack of a well-functioning enforcement agency, widespread low compliance by tax payers, and other serious problems. After the Rose Revolution, the government committed itself to deeply reforming the tax system, hoping to reduce the instances of both of tax and administrative abuse. After a year of discussion and debate, the number of taxes and their rates were reduced to the lowest levels in the region at the end of 2004.

As the result of the reform the number of taxes was reduced from over twenty to seven (six after 2008). All fiscally ineffective taxes were eliminated, and the taxes that were the main sources of corruption were abolished. The taxes remaining after the reform were those that had the most positive fiscal effects and were the easiest to calculate and pay. The combined effect of the changes in the tax regulation was associated with a $450 \%$ increase in tax revenues by 2008 during a period when the GDP only doubled. ${ }^{2}$

Table 1: Number of Taxes and Tax Rates in Georgia

\begin{tabular}{|c|c|c|c|c|c|c|}
\hline & 2003-04 & 2005 & 2006 & 2007 & 2008 & 2009 \\
\hline Number of taxes & 21 & 7 & 7 & 7 & 6 & 6 \\
\hline VAT & $20 \%$ & $20 \%$ & $18 \%$ & $18 \%$ & $18 \%$ & $18 \%$ \\
\hline Income tax & $12-20 \%$ & $12 \%$ & $12 \%$ & $12 \%$ & \multirow{2}{*}{$\begin{array}{l}\text { Soc+lnc } \\
\operatorname{tax} 25 \%\end{array}$} & \multirow{2}{*}{$\begin{array}{l}\text { Soc+lnc } \\
\operatorname{tax} 20 \%\end{array}$} \\
\hline Social tax & $33 \%$ & $20 \%$ & $20 \%$ & $20 \%$ & & \\
\hline Corporate profit tax & $20 \%$ & $20 \%$ & $20 \%$ & $20 \%$ & $20 \%$ & $20 \%$ \\
\hline Dividend income tax & $10 \%$ & $10 \%$ & $10 \%$ & $10 \%$ & $10 \%$ & $5 \%$ \\
\hline Interest tax & $10 \%$ & $10 \%$ & $10 \%$ & $10 \%$ & $10 \%$ & $5 \%$ \\
\hline Property tax ${ }^{\star}$ & $<1 \%$ & $<1 \%$ & $<1 \%$ & $<1 \%$ & $<1 \%$ & $<1 \%$ \\
\hline
\end{tabular}

Source: Ministry of Finance of Georgia

* Property tax is a local tax and its rates vary from location to location, but cannot exceed $1 \%$ of the value of the taxed property. Rates do not account for various exemptions.

From Table 1 it is clear that the most profound change in rates happened to personal income and social insurance taxes. Before the tax reform Georgia had a progressive income tax

\footnotetext{
${ }^{2}$ Authors' calculations based on macroeconomic data from the National Bank of Georgia.
} 
with marginal tax rates ranging from $12 \%$ to $20 \%$. Certain categories of individuals and income sources were exempt from individual taxes under the pre-reform regime. ${ }^{3}$

In 2005 the country switched to a flat income tax at a rate of $12 \%$. Privileges and special rates were done away with and the new tax code applied the same rate to all business activities. In addition to changes in the tax code, the government also strengthened tax collection activities by actively re-organizing tax administration, including the inspectorates at central and regional levels. Corruption among tax collectors was addressed through increased salary coupled with severe penalties including discharge for those found to be engaged in corruption. In addition, increasing public awareness on the taxpayers' rights and obligations also helped to curb bribery and tax evasion. For a discussion of these reforms, see Would Bank (2012).

The substantial of the tax reform might be expected to have had a substantial effect on the behavior of economic agents. We use a number of alternative methods to investigate whether such a change can be observed. These include methods based on macroeconomic data, such as the demand for currency, and micro-level observations of expenditure on food and the gap between income and consumption. Our analysis of macro data uses as many observations as possible to have a sufficiently lengthy time-series. Hence we look at the time span from 2000 (the earliest data was reported on a quarterly bases) to the last quarter of 2010, well after the reform took effect. When it comes to analysis of micro-level data, since we rely on a large cross-section of observations on Georgian households, we limit our time span to 2003-2007. The household survey was launched in 2003 and, even though the data quality is somewhat lower than in the following years, we still include that year in our analysis. We chose not to use data after 2007 since the Statistical Department of Georgia reports survey data from 2008 in a different format than for earlier years, making it difficult to integrate later years into our analysis.

\footnotetext{
${ }^{3}$ For example, income received by selling agricultural goods which were produced by an the individual on his/her land without further processing, income received by an individual from selling material assets (except assets used in production processes), and some other types of income were exempt from tax. Also, special social groups and individuals from high mountainous regions of Georgia if they had 3 and more children were tax exempt
} 


\section{Literature review}

Given the hidden nature of the shadow economy, researchers have developed a wide range of direct and indirect methods to measure its size. Schneider and Enste (2002) offer a concise but allinclusive survey of those methods and provide a brief survey of literature using each of these methods..

All of the methods used in literature have their disadvantages. Below we use several methods, with the hope that results from different methods will complement each other and give us a better picture of reality. Our choice of methods is based on several considerations, including: 1) occurrence in previous work, 2) desire to include both macro-data based methods as well as those relying on micro-level data, 3) data availability.

One of the most commonly used methods using aggregate (macro level) data is based on currency demand. This approach was first used by Cagan (1958), who calculated the correlation between currency demand and tax pressure (as one cause of the shadow economy) for the United States over the period 1919 to 1955. Cagan's approach was further developed by Tanzi (1983), who estimated a currency demand function for the United States for the period 1929 to 1980 in order to calculate the scale of shadow economy. This approach assumes that shadow transactions are undertaken through cash payments so as to reduce observable traces. An increase in the size of the shadow economy will, therefore, increase the demand for currency. An equation for currency demand is estimated over time, controlling for possible confounding factors such as income, payment habits, interest rates, as well as the tax burden and government regulation which are responsible for shadow economic activity and the part of demand for currency stemming from it. To isolate the "excess" or "shadow" demand for currency, this last set of variables is set to zero to estimate the demand for currency from the official economy. The residual money demand is then attributed to the shadow economy. From this excess demand one can compute the size of the shadow economy either by assuming that the velocity of shadow money is the same as in the official sector, or by estimating money velocity for the shadow sector based on data (Ahumada et. al, 2006). 
Micro-data based approaches to gauging the size of shadow economic activity rely on measuring income underreporting among households. Pissarides and Weber (1989) use a linear Engel curve to estimate the extent to which income is under-reported by certain households (headed by self-employed workers) relative to a reference group (households headed by a worker who is in contractual employment) that are assumed to fully report their income. The method relies on the fact that Engel curves, especially for food, are remarkably stable over time and across countries, and are unlikely to contain hidden expenses. Reported food consumption expenditures for the possible income under-reporters can be used to impute what their income should have been to generate the observed consumption expenditure. The difference between this imputed income and the income actually reported is used as an estimate of unreported income. More recent work in this direction has extended the model to allow for non-linear estimation of the Engel curves (Lysiotou, Pashardes, and Stengos, 2004), and non-parametric specification (Tedds, 2006).

As an alternative micro-data based method, Gorodnichenko et.al (2009) estimate the gap between household expenditures and reported income and use it as a proxy for tax evasion.

To date all such methods have relied on possibly unjustified assumption that a group of households that do not underreport income can be identified a priori. As discussed above, such an assumption, if not warranted, implies that the level of underreporting may be understated but the directional effect of policy changes can still be inferred.

\section{Methods}

In the discussion below we proceed from what we regard as the least robust in terms of underlying assumptions to the most robust method. For each method we discuss the underlying theoretical framework and main assumptions it relies on. We also discuss in detail the advantages and disadvantages of each method.

\subsection{Method A: Currency Demand Approach}

This method builds on the total demand for currency, modeled as follows:

$$
C_{T}=A(1+\theta)^{\alpha} \Upsilon_{0}^{\beta} \exp (-\gamma i)
$$


where $C_{T}$ is observed cash balances or total currency and $C_{T}=C_{0}+C_{S}\left(C_{0}\right.$ is currency used in the official economy and $C_{S}$ is shadow or excess currency), $\theta$ denotes incentives to engage in shadow activities $(0<\theta<1), Y_{0}$ is registered GDP: $Y_{T}=Y_{0}+Y_{S}\left(Y_{T}\right.$ is total GDP and $Y_{S}$ is shadow or unregistered GDP), $i$ is the opportunity cost of holding money and $\beta$ is the income elasticity of money demand. Basically, in equation (1) the term $(1+\theta)^{\alpha} \Upsilon_{0}{ }^{\beta}$ captures the effect of total GDP on currency demand, where if $\theta=0$ (there are no incentives to engage in shadow activity) $(1+\theta)^{\alpha}=$ 1 and the total GDP will be identical to official GDP. Hence, the currency demand that should be observed in an economy with no incentives to engage in shadow economic activities is expressed as:

$$
C_{0}(\theta=0)=A \gamma_{0}^{\beta} \exp (-\gamma i)
$$

The difference between the total (observed) demand for currency and the official demand from equation (2) gives the level of excess (or shadow) currency. By multiplying the excess currency $\mathrm{C}_{S}$ by money velocity in the shadow sector ${ }^{4}$ one can compute the output in the shadow sector as a percentage of observed output:

$$
r_{S}=\Upsilon_{0}\left(C_{S} / C_{0}\right)^{1 / \beta}
$$

As the motivation to engage in the shadow economic activity changes over time ( $\theta$ varies), the level of shadow GDP will also change as predicted by equations (1) to (3).By estimating $\Upsilon_{S}$ for different time periods one can observe how shadow economic activity varies over time.

\subsection{Method B: Engel Curve Estimation}

Our second approach is based on micro level data and follows the original paper by Pissarides and Weber (1989)

Suppose the food expenditure equation is given by:

$$
\ln \left(\mathrm{F}_{\mathrm{i}}\right)=\delta \mathrm{X}_{\mathrm{i}}+\beta \ln \left(\mathrm{Y}_{\mathrm{i}}^{\mathrm{p}}\right)+\varepsilon_{\mathrm{i}}
$$

where $\mathrm{F}$ is food expenditure by households (indexed by $I$ ), $Y^{P}$ is permanent income and $\mathbf{X}$ contains household characteristics. This equation cannot be estimated since the level of permanent income

\footnotetext{
${ }^{4}$ It is standard to assume that the velocity of money in the shadow sector is equal to that in the real sector (see Bajada and Schneider (2005)). We, however, follow Ahumada et al. (2006) and test this assumption. It appears that there is no significant difference in money velocity across sectors.
} 
is not observed. Firstly, a household's current income differs from permanent income: $Y_{i}=p_{i} Y_{i}^{p}$, where $p_{i}$ is a random variable. Secondly, some households underreport their income such that: $Y_{i}=$ $k_{i} Y_{\mathrm{i}}^{\prime}$ ' where $\mathrm{Y}_{\mathrm{i}}^{\prime}$ is the reported income and $k_{i}$ is a random variable that is equal to or greater than one. Given this structure, the relationship between permanent and reported income is:

$$
\ln \left(Y_{\mathrm{i}}^{\mathrm{P}}\right)=\ln \left(\mathrm{Y}_{\mathrm{i}}^{\mathrm{i}}\right)-\ln \left(\mathrm{p}_{\mathrm{i}}\right)+\ln \left(\mathrm{k}_{\mathrm{i}}\right)
$$

Assuming that $p_{i}$ is log-normal and $k_{i}$ is shifted log-normal with support on the interval $[1 ; \infty]$, one can write:

$$
\begin{aligned}
& \ln \left(\mathrm{p}_{\mathrm{i}}\right)=\mu_{\mathrm{p}}+\mathrm{u}_{\mathrm{i}} \\
& \ln \left(\mathrm{k}_{\mathrm{i}}\right)=\mu_{\mathrm{k}}+\mathrm{v}_{\mathrm{i}}
\end{aligned}
$$

where $\mu_{\mathrm{k}}=\mathrm{E}(\mathrm{k})$ and $\mu_{\mathrm{p}}=\mathrm{E}(\mathrm{p})$. For households that report their income correctly (group R) $k_{i}=1$, so $\mu_{\mathrm{k}, \mathrm{R}}=0$, and $\sigma_{\mathrm{v}, \mathrm{R}}^{2}=0$ (there is no variation in $k_{i}$ for this group). For the group of underreporting households (group UR) $k_{i}>1$ and hence $\mu_{\mathrm{k}, \mathrm{R}}>0$ and $\sigma_{\mathrm{v}, \mathrm{R}}^{2}>0$. It is assumed that the mean of $\mathrm{p}_{\mathrm{i}}$ is the same across the groups, but its variation is higher for the group of under-reporters.

Inserting (5)-(7) into the food expenditure equation (4) we get:

$$
\ln \left(\mathrm{F}_{\mathrm{i}}\right)=\delta \mathrm{X}_{\mathrm{i}}+\beta \ln \left(\mathrm{Y}_{\mathrm{i}}^{i}\right)-\beta\left[\mu_{\mathrm{p}}-\mu_{\mathrm{k}}\right]-\beta\left[\mathrm{u}_{\mathrm{i}}-\mathrm{v}_{\mathrm{i}}\right]+\varepsilon_{\mathrm{i}}
$$

If we denote $\eta_{i}=-\beta\left[\mathrm{u}_{\mathrm{i}}-\mathrm{v}_{\mathrm{i}}\right]+\varepsilon_{\mathrm{i}}$ and use a dummy variable $\mathrm{UR}=1$ for underreporting households we can rewrite this equation as:

$$
\ln \left(\mathrm{F}_{\mathrm{i}}\right)=\delta \mathrm{X}_{\mathrm{i}}+\beta \ln \left(\mathrm{Y}_{\mathrm{i}}^{\prime}\right)+\gamma \mathrm{UR}_{\mathrm{i}}+\eta_{\mathrm{i}}
$$

where

$$
\gamma=\left[-\beta\left(\mu_{\mathrm{p}}-\mu_{\mathrm{k}}\right)\right]_{\mathrm{UR}}-\left[-\beta\left(\mu_{\mathrm{p}}-\mu_{\mathrm{k}}\right)\right]_{\mathrm{R}}=\beta\left(\mu_{\mathrm{k}, \mathrm{SE}}-\left[\mu_{\mathrm{p}, \mathrm{SE}}-\mu_{\mathrm{p}, \mathrm{E}}\right]\right)
$$

In equation (9) there are several issues to consider. First, as our previous discussion suggests, there are differences in the variation of the error term across groups. Second, income 
might be endogenous, in which case IV estimation should be used, with the reduced form equation for income written as:

$$
\ln \left(Y_{i}\right)=\boldsymbol{\theta}_{1} \mathbf{X}_{i}+\boldsymbol{\theta}_{2} \mathbf{Z}_{\mathbf{i}}+\zeta_{i}
$$

where $\mathbf{Z}$ is the vector of instruments.

In both equations (9) and (10) the errors are formed from three components: $u$ - the random variation of the current income relative to permanent income, $v$ - the random variation of the reported income relative to actual income, and $\varepsilon-$ a white noise error term. As in the food consumption equation, we assume that the residual variance of errors in equation (10) is higher for the underreporting group than for those who report their income correctly.

Following Pissarides and Weber (1989), the level of underreporting can be calculated based on estimation results from equations (9) and (10). ${ }^{5}$ More specifically, the lower and upper bounds of under-reporting are computed as. ${ }^{6}$

$$
\begin{aligned}
& \ln \left(\overline{\mathrm{k}}_{\mathrm{L}}\right)=\gamma / \beta-0.5\left(\sigma_{\mathrm{Y}, \mathrm{UR}}^{2}-\sigma_{\mathrm{Y}, \mathrm{R}}^{2}\right) \\
& \ln \left(\overline{\mathrm{k}}_{\mathrm{U}}\right)=\gamma / \beta+0.5\left(\sigma_{\mathrm{Y}, \mathrm{UR}}^{2}-\sigma_{\mathrm{Y}, \mathrm{R}}^{2}\right)+\operatorname{Cov}(\mathrm{uv})_{\mathrm{UR}}
\end{aligned}
$$

where $\gamma$ and $\beta$ are coefficients from the structural equation (9), $\sigma_{\mathrm{Y}}^{2}$ is the variation in reported incomes, and $\operatorname{Cov}(\mathrm{uv})_{\mathrm{UR}}$ is the covariance between $\mathrm{u}$ and $\mathrm{v}$, which is assumed to be zero in the lower bound computations and is estimated in the upper bound calculation.

\subsection{Method C: Consumption-Income Gap Estimation}

The final technique follows Gorodnichenko et al. (2009) and uses the household incomeconsumption gap as an indirect way to capture the scale of income underreporting. This approach builds on the following relationships. Firstly, household $i$ receives income $Y_{i}$, but reports only a portion of it: $Y_{i}^{R}=\Gamma_{i} \cdot Y_{i}$, where the level of underreporting is modeled as function of observed variables: $\Gamma_{i}=\exp \left(-\boldsymbol{\gamma} \cdot \mathbf{S}_{i}+\right.$ error $\left._{i}\right)$, with $\mathbf{S}$ including job and worker related characteristics as

\footnotetext{
${ }^{5}$ The derivations are based on the assumption that variables $k$ and $p$ do indeed follow a log-normal distribution, and as a result the error terms in equations (10) and (11) follow a normal distribution, which implies that the log of income and log of food consumption also have normal distributions. Tests for normality of these variables (skewness-kurtosis and ShapiroFrancia test), however, do not support this assumption (see Table A6). The results should, therefore, be interpreted with caution.

${ }^{6}$ For details of derivations refer to the original source and/or contact the authors.
} 
well as policy measures that influence tax compliance by affecting the desire to hide income. Secondly, household income is related to permanent income $Y_{i}^{P}$ through $Y_{i}=p_{i} \cdot Y_{i}^{P}$, where now instead of assuming that $p$ is an unobserved random variable we model it as: $p_{i}=\exp \left(\boldsymbol{\eta} \cdot \mathbf{W}_{i}+\right.$ error $\left._{i}\right)$, where $\mathbf{W}$ includes life cycle factors (age, employment, number of children, etc.). Finally a household's consumption of non-durables is a portion of its permanent income: $C_{i}=\Theta_{i} \cdot Y_{i}^{P}$ where $\Theta_{i}=\exp \left(\boldsymbol{\theta} \cdot \mathbf{Z}_{i}+\right.$ error $\left._{i}\right)$ and $\mathbf{Z}$ includes various taste shifters (schooling, number of elderly household members, etc.).

Combining these 3 relationships gives the consumption-income gap (in log terms) as:

$$
\ln C_{i}-\ln Y_{i}^{R}=\boldsymbol{\gamma} \cdot \mathbf{S}_{i}+\boldsymbol{\beta} \cdot \mathbf{X}_{i}+\varepsilon_{i}(13)
$$

where $\mathbf{X}$ is the union of $\mathbf{Z}$ and $\mathbf{W}$. The variables in $\mathbf{S}$ include a dummy variable for post-reform observations that captures the effect of the tax reforms on the consumption-income gap and, thereby, reveals any changes in income under-reporting following the reform.

\section{Empirical Methodology and Data}

We now turn to the empirical application of all three methods summarized above, in the order of their discussion.

\subsection{Method A}

In order to compute the magnitude of the shadow economy using method A we estimate the following empirical version of the log of equation (1):

$$
\ln \left(C_{t}\right)=\beta_{0}+\beta_{1} \ln \left(1+\frac{T}{\mathrm{GDP}}\right)_{t}+\beta_{2} \ln \left(1+\frac{W}{\mathrm{GDP}}\right)_{t}+\beta_{3} \ln \left(G D P_{t}\right)+\beta_{4} R+\beta_{5} \pi+u_{t}
$$

where $C$ is total currency in circulation. The first two variables in equation (14) are our proxies for the "tax burden" term $(1+\theta)$ in equation (1), with T/GDP being the share of tax revenues in GDP and W/GDP denoting the share of welfare spending by government in GDP. These two variables reflect the incentives for engaging in shadow economic activity and should be positively associated with total demand for money. We then include log of GDP, which is an important determinant of currency demand because when income increases people demand more currency to support an 
increased number and size of transactions. The interest rate $(R)$ represents the opportunity cost of holding money and thus affects currency in circulation. As the most appropriate measure we use the annual rate paid on deposits of individuals. In addition to the interest rate, another factor that defines the cost of holding money, namely inflation $(\pi)$, is included in our estimates.

All variables are measured quarterly, starting from the first quarter of 2000 until the fourth quarter of 2010 , making a total of 44 quarters. Table A1 in the Appendix reports summary statistics for each variable together with the source(s) that were used to construct each time series.

To begin the empirical investigation, all series used in estimation of equation (14) were tested for unit roots using Dickey-Fuller and Phillips-Perron tests (columns 2 and 3 in Table A2 in the Appendix). The null hypothesis that the series contains a unit root is rejected only for $\ln (G D P)$ and $\ln \left(1+\frac{W}{\mathrm{GDP}}\right)$. For all the other variables, the unit root hypothesis cannot be rejected at a $1 \%$ significance level.

However, as Perron (1989) shows, when there is a structural break in a time series, conventional unit root tests are biased toward non-rejection. Perron develops a method that allows unit-root tests that control for the presence of a structural break, given that the time of the break is known. Zivot and Andrews (2002) go further by developing a procedure that determines the time of any break in the series empirically.

Given that during the period under consideration Georgia underwent several major shocks, including a change of government in 2004 followed by economic reforms, worsening of the political relations with Russia from 2006 that culminated in a war in 2008, and finally the global financial crises of 2008, just to name a few, we use the test Zivot-Andrews test. Columns 4 and 5 in Table A2 report the test statistics and the estimated timing of the breaks. We inspect all series for the possibility of several shocks. However, for each variable there is one clear shock that emerges. (See Figure A1.) According to this test, currency in circulation and GDP exhibit a structural break in the first quarter of 2008, while inflation and dollarization levels show a break in the fourth quarter of 2008. Given that 2008 was a very difficult year due to global shocks and the Russian invasion of Georgia this timing is not surprising. The remaining variables show structural breaks in earlier periods. Tax burden and interest rates change in 2004, together with the change in economic 
course of the country and start of rapid development in its banking sector, while welfare spending changes in 2007 after adoption of a new labor code and changes in social programs that followed..

Since all but 2 of the time series that we rely on follow a unit root process we test whether the series are cointegrated and find that the residuals follow a $I(0)$ process at the $10 \%$ level of significance (the test statistics from Augmented Engle-Granger test is -3.71 , which is only slightly above the $5 \%$ critical level of -3.78 , and well below the $10 \%$ critical level of -3.5$)$. We can, therefore, estimate equation (14) to capture the long-run relationship between currency in circulation and the right-hand-side variables. Table 2 (column 2) reports the results from this estimation.

In most applications of the currency demand approach, national currency is assumed to be the main mean for transactions. An important feature of the Georgian economy, however, is its high level of dollarization. ${ }^{7}$ Hence, we experiment with including a measure of dollarization. Over time, the Georgian Lari (GEL) has been gaining importance in the Georgian economy and relatively more transactions have been conducted in GEL rather than in USD. To the extent that this trend is leading to an increase in the demand for national currency, it might be important to control for the extent of dollarization when estimating the demand for national currency. We use the percentage of bank deposits in dollars as a fraction of all deposits to capture the level of the economy's dollarization. Table 2 (column 3) contains estimates from this extended specification of the model. We do not find a significant impact on demand for the GEL from the level of dollarization.

\footnotetext{
${ }^{7}$ According to the 'Financial Stability Reports' from the National Bank of Georgia, the share of loans issued by Georgian banks that were denominated in USD was as high as $88 \%$ in 2003 (decreasing to $72 \%$ in 2007) while the share of bank deposits in USD ranged between 67 percent in 2004 and 50 percent in 2007. Indeed, even today most ATMs in Georgia dispense both Lari and US Dollars.
} 
Table 2: Regression Results, Method A

\begin{tabular}{|c|c|c|}
\hline Variable & Model 1 & Model 2 \\
\hline Log of GDP & $\begin{array}{l}1.190^{* * *} \\
(0.047)\end{array}$ & $\begin{array}{l}1.184^{* * *} \\
(0.047)\end{array}$ \\
\hline Inflation & $\begin{array}{l}-0.003 \\
(0.004)\end{array}$ & $\begin{array}{l}-0.006 \\
(0.004)\end{array}$ \\
\hline Interest Rate & $\begin{array}{l}-0.018^{* *} \\
(0.007)\end{array}$ & $\begin{array}{c}-0.022^{\star * *} \\
(0.008)\end{array}$ \\
\hline Log of (1+tax/DGP) & $\begin{array}{l}1.314^{*} \\
(0.697)\end{array}$ & $\begin{array}{c}0.594 \\
(0.886)\end{array}$ \\
\hline Log of (1+welfare/GDP) & $\begin{array}{l}2.106^{\star * *} \\
(0.666)\end{array}$ & $\begin{array}{l}2.170^{* * *} \\
(0.662)\end{array}$ \\
\hline Dollarization & & $\begin{array}{l}-0.004 \\
(0.003)\end{array}$ \\
\hline Quarter 1 & $\begin{array}{l}0.140^{\star \star \star} \\
(0.028)\end{array}$ & $\begin{array}{l}0.146^{* \star *} \\
(0.028)\end{array}$ \\
\hline Quarter 2 & $\begin{array}{c}0.023 \\
(0.023)\end{array}$ & $\begin{array}{c}0.024 \\
(0.025)\end{array}$ \\
\hline Quarter 3 & $\begin{array}{c}0.017 \\
(0.025)\end{array}$ & $\begin{array}{c}0.018 \\
(0.024)\end{array}$ \\
\hline Intercept & $\begin{array}{c}-3.087^{\star \star *} \\
(0.329)\end{array}$ & $\begin{array}{c}-2.657^{* * *} \\
(0.465)\end{array}$ \\
\hline $\mathbf{R 2}$ & 0.993 & 0.993 \\
\hline RESET (yhat ${ }^{2}$ ) & $-0.102(0.068)$ & \\
\hline $\mathbf{N}$ & \multicolumn{2}{|c|}{44} \\
\hline
\end{tabular}

Note: Estimates are based on cointegrated model (4). ${ }^{*} p<0.1 ;{ }^{* \star} p<0.05 ;{ }^{* \star *} p<0.01$, standard errors in parenthesis.

One problem in the extended regression is the high level of correlation between variables, creating multicollinearity problems (see Table A3 in the Appendix). The variable-pairs that cause the biggest problem are between the log of GDP and tax burden as well as dollarization and tax burden. The result is that the coefficient estimate on the tax burden in the regression is insignificant. Given that the dollarization rate is far from being significant, we focus on the estimates without dollarization. The problem of multicollinearity remains even after dropping dollarization rate (the correlation between tax burden and GDP, for example, is 0.88 ), however the 
tax burden variable is now found to be positive and significant. As a RESET test shows, there is no evidence of functional form misspecification in the model reported in column 2 of Table $2 .{ }^{8}$

Continuing with the specification that omits dollarization rate, we fit a model with leads and lags model to test whether the coefficient on log GDP is different from one (indicating a different money velocity in the official and shadow economies) and cannot reject the possibility that money velocity in the two sectors is the same ( $p$-value from the test is 0.16$),$. We, therefore, apply a simple formula for inferring the size of shadow activity by assuming $\beta=1$. Figure 1 displays the estimated evolution of the size of the shadow economy. It appears that the scale of shadow economic activity is in the range of $20-30 \%$ in the pre-reform period and increases after the tax reform of 2005 to $40-50 \%$. This result is surprising for two reasons. First the estimation for the initial years in the period are much lower than the estimates suggested by Schneider et al. (2010), which are as high as $68.8 \%$ of official GDP. The difference in results could be due to difference in estimation technique. Schneider uses the dynamic multiple indicator multiple cause estimation (DYMIMIC) to trace relative changes in the size of shadow economies of 151 countries. To translate changes to absolute values he anchors DYMIMIC indicator to estimates from a currency demand approach performed for a few countries (excluding Georgia) and then extrapolates results for all sample countries. In our case we use macro data for Georgia to directly estimate the size of shadow economy. Also, the time period used in our estimation is more recent, which could further drive the difference between our results and those of Schneider.

The second surprising finding from this method is that the size of the shadow economy in Georgia apparently increases following reform, the opposite of what would be expected given the change in tax system.

\footnotetext{
${ }^{8}$ The t-statistic on the included square of the predicted values from the model is -1.5 , which rejects the importance of higher order terms in the model.
} 
Figure 1: The Dynamics of the Shadow Economy, Method A

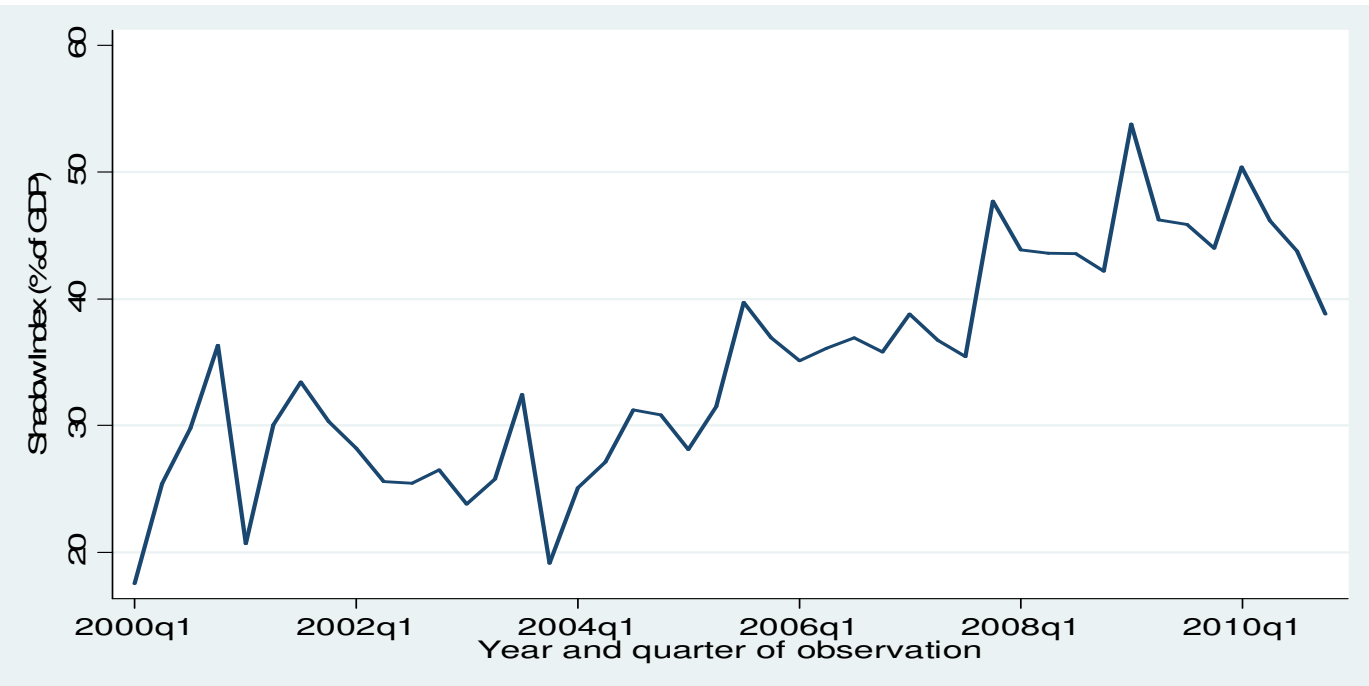

There are, however, several problems with applying this estimation technique. An important issue is the definition of the tax burden. Ideally this variable would reflect the actual burden of taxes on economic agents. It currently, however, mixes this with the size of the tax base, making it difficult to separate the effect of rates. It would also be good to control for tax enforcement. Unfortunately, these variables are not available on a quarterly basis. Another problem is the omission of potentially important variables that might have influenced money demand in Georgia over the period we are studying. For example, the level of remittance inflows into the country grew dramatically, from $2 \%$ of GDP in 2001 to around $8 \%$ of GDP by the end of the decade. ${ }^{9}$ Also, the Georgian government received received large foreign grants ${ }^{10}$ during the later years in our sample. Capital inflows were also sizeable, with FDI inflows increasing from $7 \%$ of GDP in 2005 to $17 \%$ of GDP in 2007 , before falling back to $7 \%$ by 2010 . To the extent these factors fueled currency demand, our estimates of the effect of the influence of tax reforms on the size of shadow economy could be biased.

\footnotetext{
${ }^{9}$ Source: National Bank of Georgia

${ }^{10}$ Source: Ministry of Finance of Georgia
} 


\subsection{Method B}

Our next empirical exercise is estimation of the size of shadow economy following Pissarides and Weber (1989). We apply this technique using household survey data ${ }^{11}$ for Georgia for the years 2003-2007. The survey is conducted quarterly and in each quarter some households are replaced by new observations. We merge data for all non-repeat households surveyed in any given year to obtain an extended cross-section sample. This gives us a starting number of more than 5000 households annually. Given that we know the quarter of each observation we use quarter dummies to control for season-specific fluctuations. Also, we use regional dummies to control for area-specific fixed effects.

The main variables in our analysis are monthly food expenditure aggregated from a diary reported by surveyed households on daily basis (see the Appendix for more details on variable construction), and household income calculated from the combined income reported by all household members from all jobs and other regular sources

A crucial part of this estimation method is splitting households into two groups, one that is assumed to report both their food expenditure and income correctly and second that assumed to correctly report food expenditure but under-report income. Pissarides and Weber split their sample into self-employed households (defined as those with income from self-employment above $25 \%$ of total household income) as the group of under-reporters and employed families (with income from self-employment below $25 \%$ of overall income) as the group assumed to report income correctly. Given that this approach depends on the level of reported income, to the extent reported income is distorted for under-reporters some families will be misclassified. A second problem is that the assumption that all wage and salary earners fully report income is not empirically justified (see Kolm and Nielson (2008) and European Commission (2007)). The implication is that estimating the shadow economy using such a method will be biased downwards although, as discussed above, trends might still be observable. We define the "self-employed" (under-reporting) group as

\footnotetext{
${ }^{11}$ The survey is geographically and demographically representative and collects data on a large number of households. The survey started in 2003, and is still being implemented on an annual basis. We do not use the data after 2007, however, due to changes in the data structure that took place from 2008-onward.
} 
households where the head is either self-employed or is a non-wage laborer. ${ }^{12}$ As is common in the literature, we classify households by the type of employment of the head only. (See, for example, Gorodnichenko, (2009).) In our data this classification is highly correlated with alternatives such as classification according to the status of the highest earning household member. We recognize that it may understate unreported earnings when there are more than one self-employed earner, but as long as the proportion with multiple possible hiders remains constant before and after the tax reform, this will bias the size of our estimates but not the intertemporal pattern.

The following types of employment are reported by survey respondents:

1. Employee, working for fixed salary on the basis of a written or oral contract

2. Employer (entrepreneur, farmer working at his own enterprise)

3. Person working on his own account in nonagricultural sector or involved in professional activities without employees, professional activities

4. Farmer working on private or rented land (without employees)

5. Non-wage laborer in a household enterprise

6. Non-wage laborer working for a friend or relative

7. Other

Based on this list, if the head of household is in category 1 the household is classified as employed. Households where the head is in categories 3 and 5 are categorized as self-employed. Categories 2 and 6 comprise a very small share of the sample (around $1 \%$ of individuals) and are omitted from the analysis. Category 4, farmers, is also excluded from the analysis, since households led by a farmer might be consuming a substantial amount of home-grown food, thereby lowering reported cash food expenditures and including these households in the analysis might distort the overall food expenditure pattern.

The share of households of different types in the sample with complete incomeexpenditure data is stable over time. Employed households comprise $41 \%$ of the sample, while the

\footnotetext{
${ }^{12}$ A substantial share of households in Georgia has one or more members who report themselves to be non-wage workers in a household enterprise, consequently reporting no income. In most cases those non-wage laborers receive some compensation for their work, and one can, therefore, justify adding these cases to the group of households that are likely to underreport their income.
} 
share of self-employed households is around $16 \%$. Some $13 \%$ of households are led by farmers, and the remaining $30 \%$ are led by a head who did not report any employment status.

Summary statistics for income and food expenditure for the years under consideration are given in Table A4. ${ }^{13}$ All in all, we end up with an average of 450 complete observations for selfemployed households and 1200 observations for employed households each year.

On average, real food consumption stays the same over time, while real income rises very slowly for the self-employed group and more rapidly for the employed households. The variation in income is higher than that for food expenditure in the beginning of the period and widens by the end of the period studied, mostly due to increased variation in incomes among employed families. Self-employed households earn less on average than employed households starting from 2005. This might be due to a sharp increase in salaries for some public jobs ${ }^{14}$ that took place after 2005, and also to an improved economic climate that expanded the operation of businesses that hire on the bases of contracts (banking sector, companies with foreign owners, international organizations, etc.). On average, the share of food expenditure in total income is higher for self-employed households, and ranges between $60-70 \%$ for various years. The share of food expenditure for employed households is around $72 \%$ for 2003 and drops to below $50 \%$ in 2007 .

Variables in the vector $\mathbf{X}$ include the age, gender, education and marital status of the head of the household, and the number of disabled, elderly, children and adults in the households. See Table A5 in the Appendix for variable definitions and summary statistics. Instruments (variables in Z) include ownership of a car and a TV, the head of the household's partner having employment in the previous 3 months, and the partner being self-employed. See the Appendix for details.

Turning to the estimation of the model, we first perform tests for normality of the variables and group-wise heteroskedasticity. We that the assumption that variables are normally distributed generally fails (see Appendix Table A6) and that for some years variances for income as well as for food expenditure across groups are not equal. Also, the log of income is tested for endogeneity

\footnotetext{
${ }^{13}$ Approximately half of households led by a self-employed head and one third of households led by an employed head are missing income data.

${ }^{14}$ According to the survey, after 2004-2005 the number of households where the head is employed in the public sector more than doubles compared to 2003 and the average income that those households report increases, especially in 2006-2007. The pre-reform share of household heads employed in the public sector is only about $20 \%$ of the total number of "employed" households.
} 
and is found to be such for the last 2 years under consideration (see Table A7 in the Appendix). Given that there is evidence of heteroskedasticity and endogeneity of income for at least some years, we incorporate a weight correction for unequal variances in our estimations and proceed with IV estimation of the model.

Table 3 presents results from model estimation for various years. In Table 4 we present estimates for the key parameters used for calculation of the extent of underreporting.

Table 3: Main Estimation Results, Method B

\begin{tabular}{|c|c|c|c|c|c|}
\hline Main variables & 2003 & 2004 & 2005 & 2006 & 2007 \\
\hline Log of income & $0.30^{* * *}$ & $0.30^{* * *}$ & $0.21^{* *}$ & $0.44^{* * *}$ & $0.48^{* * *}$ \\
\hline Self-employed HH & 0.03 & $0.10^{*}$ & -0.03 & 0.07 & $0.12^{* *}$ \\
\hline \multicolumn{6}{|l|}{ Head of HH characteristics } \\
\hline Male & -0.09 & -0.12 & 0.04 & -0.06 & $-0.11^{*}$ \\
\hline Married & $0.14^{* *}$ & $0.13^{*}$ & 0.08 & 0.08 & 0.07 \\
\hline Elementary education & -0.01 & -0.03 & $-0.39^{*}$ & $-0.35^{*}$ & -0.00 \\
\hline Incomplete sec. educ. & -0.04 & 0.22 & $-0.42^{* * *}$ & -0.03 & 0.06 \\
\hline Vocational-technical educ. & 0.06 & 0.13 & 0.02 & 0.02 & -0.14 \\
\hline Special secondary educ. & 0.06 & $0.14^{*}$ & -0.09 & 0.04 & 0.07 \\
\hline Higher education & $0.17^{\star * *}$ & $0.14^{*}$ & $0.11^{*}$ & 0.06 & 0.11 \\
\hline Age & 0.01 & -0.01 & 0.01 & 0.01 & 0.00 \\
\hline Age sq. & -0.00 & 0.00 & -0.00 & -0.00 & 0.00 \\
\hline \multicolumn{6}{|l|}{$\mathrm{HH}$ characteristics } \\
\hline Presence of disabled & $0.12^{*}$ & 0.03 & -0.04 & $-0.13^{*}$ & -0.04 \\
\hline Number of old people & -0.06 & -0.00 & -0.03 & -0.04 & -0.04 \\
\hline Number of adults & $0.09^{* * *}$ & $0.09^{* * *}$ & $0.11^{* * *}$ & $0.08^{* * *}$ & $0.07^{* * *}$ \\
\hline Number of kids, $0-5$ years & $0.17^{\star \star *}$ & $0.12^{\star *}$ & 0.04 & $0.12^{\star \star}$ & 0.07 \\
\hline Number of kids 6-16 years & $0.10^{* * *}$ & $0.14^{* * *}$ & $0.14^{* * *}$ & $0.06^{* *}$ & $0.14^{* * *}$ \\
\hline HH from urban area & $0.31^{* * *}$ & $0.34^{\star \star \star}$ & $0.31^{* \star *}$ & $0.27^{\star \star *}$ & $0.24^{\star \star *}$ \\
\hline Constant & $1.84^{\star * *}$ & $2.00^{\star \star \star}$ & $2.31^{* * *}$ & $1.49^{* * *}$ & $1.49^{* \star *}$ \\
\hline $\mathbf{N}$ & 1743 & 1680 & 1637 & 1569 & 1565 \\
\hline r2 & 0.33 & 0.26 & 0.33 & 0.28 & 0.26 \\
\hline
\end{tabular}

Notes: IV estimation with group-wise heteroskedasticity; ${ }^{*}$ - significant at $10 \%$, ${ }^{* *}$ - significant at $5 \%$, ${ }^{* * *}$ - significant at $1 \%$; estimation includes year and region fixed effects, which are not reported here. 
Table 4: Estimated Level of Income Underreporting by Self-Employed Households

\begin{tabular}{|c|c|c|c|c|c|c|}
\hline Year & $\mathbf{B}$ & $\square$ & $\mathrm{SD}(\zeta, \mathrm{SE})$ & $\mathrm{SD}(\zeta, \mathrm{E})$ & Est(Ik) & Est(uk) \\
\hline $\mathbf{2 0 0 3}$ & $\begin{array}{c}0.298 \\
(0.070)\end{array}$ & $\begin{array}{c}0.027 \\
(0.043)\end{array}$ & 0.872 & 0.681 & 0.94 & 3.66 \\
\hline $\mathbf{2 0 0 4}$ & $\begin{array}{c}0.304 \\
(0.092)\end{array}$ & $\begin{array}{c}0.100 \\
(0.048)\end{array}$ & 0.849 & 0.695 & 1.23 & 4.58 \\
\hline $\mathbf{2 0 0 5}$ & $\begin{array}{c}0.214 \\
(0.074)\end{array}$ & $\begin{array}{c}-0.032 \\
(0.045)\end{array}$ & 0.607 & 0.617 & 0.87 & 1.82 \\
\hline $\mathbf{2 0 0 6}$ & $\begin{array}{c}0.439 \\
(0070)\end{array}$ & $\begin{array}{c}0.066 \\
(0.044)\end{array}$ & 0.617 & 0.606 & 1.15 & 2.46 \\
\hline $\mathbf{2 0 0 7}$ & $\begin{array}{c}0.481 \\
(0.074)\end{array}$ & $\begin{array}{c}0.122 \\
(0.043)\end{array}$ & 0.567 & 0.616 & 1.33 & 2.59 \\
\hline
\end{tabular}

Note: Standard errors in parenthesis

We can see these results more easily in Figure 2 where we plot smoothed, estimated underreporting bounds. Looking at the dynamics of the upper bound, there appears to be a reduction in 2005 in the level of relative underreporting by self-employed families compared to the employed households. The level of underreporting by the self-employed seems to be going back up in the last 2 years under consideration, possibly capturing the fact that some households partially adjusted to the new tax regulations and continue underreporting their income even under the new regime. Looking at the lower-bound levels of underreporting, however, there is no sizable difference between the level of underreporting by different types of households either before or after the reform. Overall, the results from this method suggest some reduction in income underreporting after the tax reform in Georgia, however, given the wide deviation between the lower and upper bound estimates, they are not very conclusive. 
Figure 2: Income Underreporting by Self-Employed Relative to Employed Households

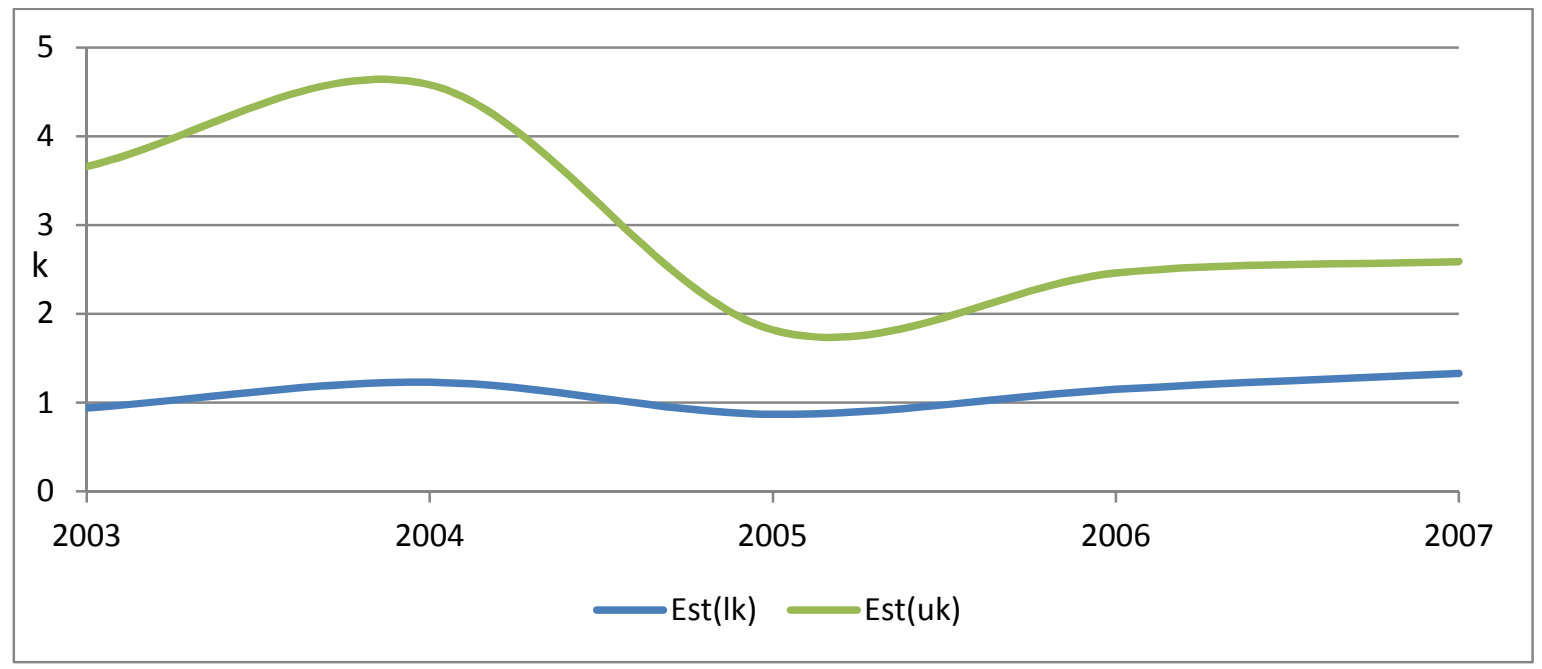

While our findings suggest possible changes in the reporting of income by households that coincided with changes in the tax regulation, there are several issues related to the method applied in this section that should be noted.

First, as was mentioned above, certain assumptions (i.e. log-normality of income) that this method builds on are not satisfied by the data. Given that these assumptions are important for the final results, the extent of income underreporting may have been miscalculated.

Second, one has to understand that this method computes the level of underreporting of one group of households relative to a base group that is assumed to fully report their income. If, as discussed above, this latter group also underreports their income (perhaps to a lesser degree than the first group) the extent of underreporting in society as a whole will be understated. Also, a nontrivial share of households has been excluded from the analysis. Although our choice of household types follows previous studies (Pissarides and Weber (1989)), as is shown below, there is more similarity between employed and self-employed households in Georgia than one would expect in terms of income underreporting, while other types of households seem to stand out as those where underreporting might be a bigger issue. 


\subsection{Method C}

The data for this approach come from the same household survey used in method B. Many variables are also common across methods. The starting number of observations we use here is 14,481 , where we exclude households with at least one member reporting a paid job but no earnings. Table A8 in the appendix presents summary statistics for the variables of interest.

The dependent variable in this method is the consumption-income gap, which is defined as the log of household consumption minus the log of household income. ${ }^{15}$ For robustness, we use several alternative definitions of consumption and income. More specifically, we define a narrow concept of consumption $\mathrm{C} 1$, which includes monthly household expenditure on food and non-food items (excluding durables) and more extended versions of consumption - C2 which adds payments to other households to $\mathrm{C} 1$, and $\mathrm{C} 3$, which adds purchases of durable goods to $\mathrm{C} 1$. As for income, Y1 combines all regular labor and non-labor types of income; while $Y 2$ adds also non-regular inflows of funds to $Y 1$, and $Y 3$ expands $Y 1$ to include revenues from household production. See the Appendix for more information about variable definitions.

Using various definitions of consumption and income we build Gap1= $\ln C 1-\ln Y 1$, Gap2=InC2-InY2, and Gap3=InC3-InY3. We experimented with other combinations of consumption and income definitions including the total of all consumption with the findings unchanged.

To control for possible shrinking in the consumption-income gaps in the post-reform period we use a post-reform dummy variable, taking a value of 1 for the years 2005-2007. Estimation results are presented in Table 5 (see Initial Estimations columns). We control for time and region fixed effects (not shown in the table), estimate robust standard errors, and allow for clustering of errors at the regional level.

\footnotetext{
${ }^{15}$ Note that in our context, $C_{i}$ will usually be less than $Y_{i}$, so that $\log C_{i}-\log Y_{i}$ is less than one. In some 30 percent of households, however, reported consumption is greater than reported income, making the gap positive.
} 
Table 5: Estimation Results, Method C

\begin{tabular}{|c|c|c|c|c|c|c|}
\hline \multirow[b]{2}{*}{ Variables } & \multicolumn{3}{|c|}{ Initial Estimation } & \multicolumn{3}{|c|}{ Extended Estimation } \\
\hline & Gap 1 & Gap 2 & Gap 3 & Gap 1 & Gap 2 & Gap 3 \\
\hline Intercept & $2.09^{* * *}$ & $3.12^{* \star *}$ & $4.01^{* * *}$ & $2.25^{\star \star \star}$ & $3.44^{* * *}$ & $4.26^{* * *}$ \\
\hline \multicolumn{7}{|l|}{ Head of HH characteristics } \\
\hline Age & $0.04^{\star \star *}$ & $0.06^{\star \star *}$ & $0.04^{*}$ & $0.04^{* * *}$ & $0.06^{* * *}$ & $0.04^{*}$ \\
\hline Age square & $-0.00^{\star * *}$ & $-0.00^{* * *}$ & $-0.00^{* *}$ & $-0.00^{* \star *}$ & $-0.00^{\star * *}$ & $-0.00^{* *}$ \\
\hline Married & $0.20^{* * *}$ & $0.15^{\star}$ & $0.29^{* * *}$ & $0.20^{\star * *}$ & $0.15^{\star *}$ & $0.29^{* \star *}$ \\
\hline Male & $-0.28^{* *}$ & -0.05 & $-0.38^{* *}$ & $-0.27^{* *}$ & -0.05 & $-0.38^{* *}$ \\
\hline Elementary education & $-0.35^{* * *}$ & $-0.44^{* *}$ & $-0.38^{*}$ & $-0.37^{\star *}$ & $-0.48^{* *}$ & $-0.41^{*}$ \\
\hline Incomplete sec educ. & -0.14 & -0.09 & $-0.26^{*}$ & $-0.16^{*}$ & -0.13 & $-0.28^{*}$ \\
\hline Vocational-technical educ. & 0.02 & -0.03 & 0.04 & 0.02 & -0.03 & 0.04 \\
\hline Special secondary educ. & $0.16^{*}$ & $0.25^{*}$ & $0.22^{*}$ & $0.15^{\star}$ & $0.24^{*}$ & $0.22^{*}$ \\
\hline Higher education & $0.12^{*}$ & $0.15^{*}$ & $0.21^{* *}$ & $0.11^{*}$ & $0.13^{*}$ & $0.21^{* *}$ \\
\hline Had job in the last 7 days & $-0.53^{*}$ & $-0.76^{*}$ & $-0.86^{*}$ & $-0.50^{*}$ & $-0.71^{*}$ & $-0.84^{*}$ \\
\hline Had contractual job & $-2.04^{* * *}$ & $-2.90^{* * *}$ & $-3.41^{* * *}$ & $-2.34^{* * *}$ & $-3.50^{\star * *}$ & $-3.80^{* * *}$ \\
\hline Was self-employed & $-2.09^{* * *}$ & $-2.96^{\star * *}$ & $-3.42^{* * *}$ & $-2.42^{* * *}$ & $-3.54^{* * *}$ & $-3.86^{* * *}$ \\
\hline Was a farmer & -0.01 & -0.10 & $-0.58^{*}$ & 0.31 & 0.42 & -0.44 \\
\hline Had a non-paid job & $-0.28^{*}$ & $-0.46^{*}$ & $-1.01^{* * *}$ & $-0.63^{* *}$ & $-1.07^{* * *}$ & $-1.49^{* * *}$ \\
\hline \multicolumn{7}{|l|}{ HH characteristics } \\
\hline Number of members & $0.08^{* * *}$ & 0.02 & $0.07^{*}$ & $0.08^{\star \star \star}$ & 0.02 & $0.06^{*}$ \\
\hline Number of old people & $-0.23^{\star * *}$ & $-0.36^{* * *}$ & $-0.41^{* * *}$ & $-0.23^{* * *}$ & $-0.36^{\star * *}$ & $-0.41^{* * *}$ \\
\hline Number of kids, 0-5 years & -0.03 & -0.02 & -0.04 & -0.03 & -0.02 & -0.03 \\
\hline Number of kids $6-16$ years & 0.00 & -0.00 & -0.04 & 0.01 & 0.00 & -0.04 \\
\hline Members with primary ed. & -0.06 & 0.00 & -0.02 & -0.06 & -0.00 & -0.02 \\
\hline Presence of disabled & $-0.43^{* * *}$ & $-0.66^{* * *}$ & $-0.76^{* * *}$ & $-0.42^{* * *}$ & $-0.64^{* * *}$ & $-0.75^{* * *}$ \\
\hline Urban area (excl. Tbilisi) & $0.15^{\star}$ & 0.03 & $0.53^{\star \star \star}$ & $0.15^{\star}$ & 0.03 & $0.52^{* * *}$ \\
\hline HH from Tbilisi & $0.34^{\star \star \star}$ & $0.24^{\star * *}$ & $0.65^{\star * *}$ & $0.34^{\star * *}$ & $0.23^{\star \star *}$ & $0.65^{\star * *}$ \\
\hline \multicolumn{7}{|l|}{ Post-reform dummies } \\
\hline After reform years & $-0.34^{\star * *}$ & $-0.43^{* * *}$ & $-0.25^{\star *}$ & $-0.55^{\star * *}$ & $-0.88^{* * *}$ & $-0.62^{* *}$ \\
\hline Self-employed x After & & & & $0.52^{\star \star *}$ & $0.93^{* * *}$ & $0.74^{* *}$ \\
\hline Employed x After & & & & $0.47^{* *}$ & $0.97^{* *}$ & $0.66^{\star *}$ \\
\hline Farmer x After & & & & $-0.56^{* *}$ & $-0.89^{* *}$ & -0.24 \\
\hline $\mathbf{R 2}$ & 0.37 & 0.30 & 0.37 & 0.38 & 0.32 & 0.37 \\
\hline $\mathbf{N}$ & & 14480 & & & 14480 & \\
\hline
\end{tabular}

The size of the consumption-income gap is significantly lower in the post-reform years. The average width of the gap (Gap 1) in pre-reform years was 1.14, which, on average, corresponds to 
consumption being roughly three 3 times reported income. ${ }^{16}$ The estimated coefficient of -0.34 on the post-reform dummy suggests a 30\% reduction in Gap1. This reduction corresponds to consumption being only twice reported income on average in the post-reform period.

To better understand how different types of households adjusted to the tax reform, we introduce several interaction terms where the type of the household is multiplied by the post-reform dummy. In essence, we allow the post-reform adjustment to be different across various types of households. Results are reported in the last 3 columns of Table 5 . Recall that households are classified by the employment status of their head including those who are employed (on a contract), self-employed (including households with members who work without pay), farmers, and finally households led by a head who does not belong to any of the above categories. This last group is used as the base or reference category.

In the pre-reform period employed and self-employed households had the lowest discrepancy between consumption and income levels. Households with a non-paid head follow, while households headed by farmers and the rest of the sample have the highest level of discrepancy (hence, the highest implied underreporting of income). The gap post reform significantly decreases for reference group of non-classified households as can be seen from the estimate on the post-reform dummy. It decreases even further for farm households, where the effect is pretty much double that for non-classified households. To give an idea about the size of the adjustment estimated for farm households, we note that the consumption level for this group in the pre-reform period is six times the reported income while post-reform it is only twice as large.

Finally, we note that the estimates for the self-employed and employed household interaction terms completely cancel out the after-reform effect, indicating that these two groups experienced the smallest adjustment in their (already low) gap between consumption and income. The similarity of the employed and self-employed groups before the reform combined with their

\footnotetext{
${ }^{16}$ In pre-reform years the average value of the consumption-income gap is $\operatorname{LnC}-\ln Y=\ln (C / Y)=1.14$, so $C / Y=\exp (1.14)=3.13$, approximately. In post-reform years the size of the gap, other things being constant, is reduced by 0.34 , so $\ln C-\ln Y=0.8$ and $C / Y$ can be approximated as $\exp (0.8)=2.23$.
} 
similar adjustment to the reform can explain why the lower bound in Method B did not capture relatively greater underreporting among the self-employed.

Gorodnichenko et al. (2009) discuss and dismiss the possibility of previously accumulated assets and dis-savings being used to finance households' consumption-income gap, arguing that by the mid-1990s the value of accumulate assets was very low and if the observed consumptionincome gap were due to dis-savings, it would require a huge reduction in assets that would be impossible to sustain for such a long time period. Given that Georgia experienced a much deeper recession in the beginning of its transition than even Russia (as well as extensive anecdotal evidence), we believe that the availability of financial assets to Georgian households in the period preceding the reforms was even worse than that of Russian families. Data on savings rates from 2001 on show that savings and lending were comparable to Russian data, constituting $4-7 \%$ of household total expenditures (See Figure 3). It should be noted that the Georgian savings rate shows a sharp reduction in 2005-2007 while we do not observe a similar change in the incomeconsumption gap during this period.

Figure 3: Household Savings as Share of Expenditure

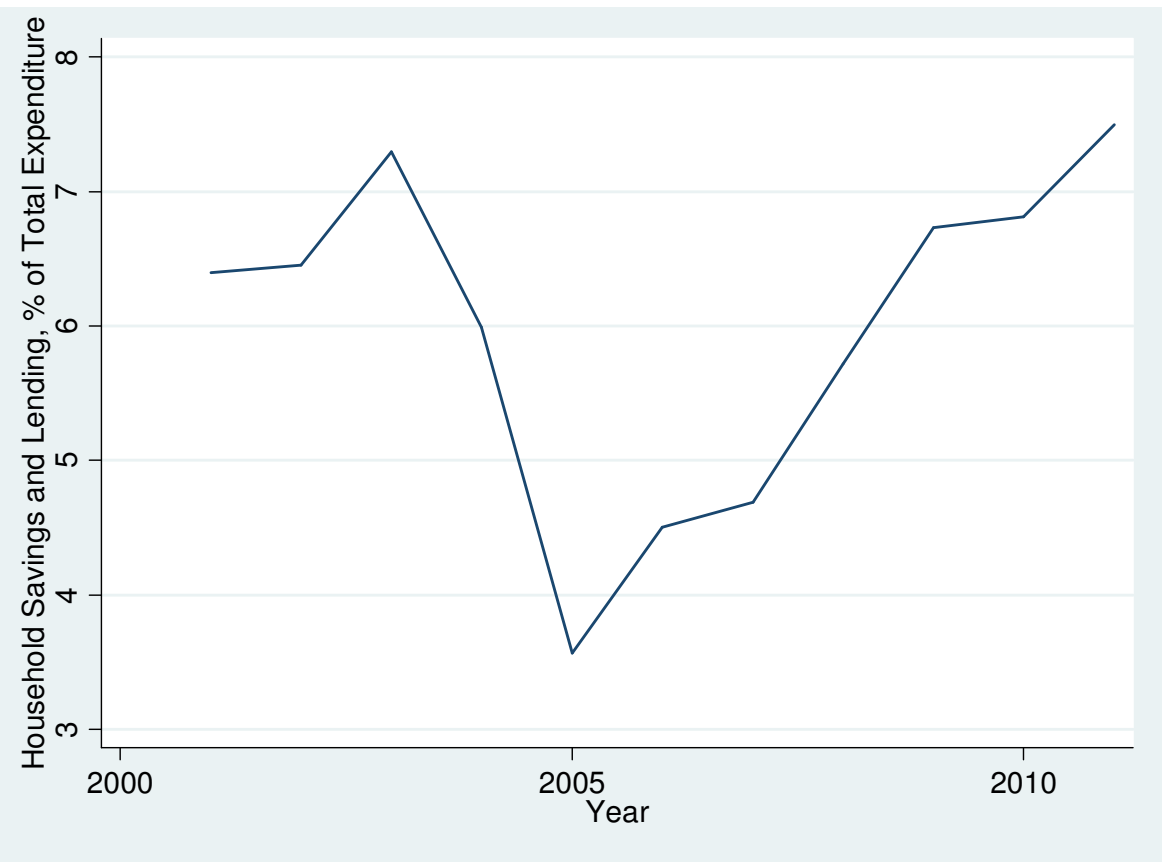

Source: National Statistics Office of Georgia 
Gorodnichenko et al. (2009) focus on study of the Russian flat tax reform of 2001. As in our case, they document a decrease in the consumption-income gap following the tax reform. They also try to separate the pure effect of the change in tax rates on the size of Russian shadow economy from the effect of other changes, including stricter tax enforcement, on income underreporting. To do so they use the fact that some households that had low pre-reform income, and were already subject to the lowest tax rate of $13 \%$ should not be affected by the reform. On the other hand, households with income above the $13 \%$ threshold would be subject to higher tax rates in the pre-reform years and would shift to the lower level of flat tax in post reform years. Hence, the authors treat this group as the treatment group. They find a reduction in the consumption-income gap for the treatment group in post-reform years, which they attribute to the change in the tax rate and not the level of enforcement (because the latter would affect both control and treatment households).

We try a similar exercise for Georgia, where we categorize households where the head of household is earning more than $200 \mathrm{GEL}$ - the cutoff point for the higher tax bracket in the prereform period, as the treatment group, and those with a head earning less than 200 GEL as the control group. We repeat the regressions with the before/after dummy variable and add a dummy variable that takes value 1 for our treatment group, as well as an interaction variable between the period after reform and being in the treatment group to check if adjustment in the consumptionincome gap differs across the treatment and control groups. Our findings (the key coefficient estimates are summarized in Table 6) indicate that households in the treatment group have a smaller consumption-income gap compared to those in the control group, after we control for the observed characteristics of the household and its head (not shown in the Table). The control group seems to improve its income reporting in the years following the reform (the gap is significantly smaller for this group in the after-reform period). Compared to this group, the treatment group shows much smaller adjustment to the reform: the coefficient estimate on the treatment*after interaction term is positive, reducing the overall change in the gap in post-reform period. 
Table 6: Key Results from Difference-in-Differences Estimation

\begin{tabular}{|l|l|l|l|}
\hline Variables & Gap 1 & Gap 2 & Gap 3 \\
\hline After & $-0.374^{\star * *}$ & $-0.582^{* * *}$ & $-0.354^{* * *}$ \\
\hline Treated & $-1.60^{* * *}$ & $-1.656^{* * *}$ & $-1.758^{\prime \prime \prime \prime}$ \\
\hline Treated x After & $0.163^{* * *}$ & $0.337^{* * *}$ & $0.224^{* * *}$ \\
\hline $\mathbf{R}^{2}$ & 0.410 & 0.320 & 0.395 \\
\hline
\end{tabular}

The treatment group was subject to a change in the tax rate (they were subject to tax of up to $20 \%$ before the reform and are only facing a 12 percent rate in the post reform period) as well as stricter tax enforcement, while the control group has been subject to change in tax enforcement only. These findings suggest an issue of endogeneity, whereby households fell into the "control" group because they were hiding income prior to the reform. It could be that in Georgia the shift to flat tax by itself did not lead to a reduction in underreporting of income. Rather the change that we document in income reporting may be mostly due to better enforcement of tax regulations. We would like to point out, however, an important difference between the work by Gorodnichenko et al. and our estimation. While Gorodnichenko et al. rely on panel data, which allows controlling for household-specific fixed effects, we have to work with an independent random cross-section of households in each year, and hence, cannot control for unobserved household heterogeneity.

Another thing that is worth noting here (and in the paper by Gorodnichenko et al.) is that there were many other changes happening in Georgia (and in Russia) during the years under consideration. To the extent these changes led to adjustments in consumption-income behavior of the households we would confine their effect with that of the change in tax regulation. We believe, however, that the tax regulation was the most important change that affected income of most households and had a strong and direct impact on their consumption-income behavior. Another potentially big shock for the households was a drastic change in the labor code, but this took place only after 2006 and would probably require a longer period for adjustments in behavior since it had to first pass through the institutional framework of the labor market.

\section{Conclusions}


This paper applies 3 different methods widely used in the literature to track changes in shadow economic activity in Georgia following a tax level and enforcement reform in 2005. The first method is based on currency demand. Using this method we do not find a significant relationship between the tax burden and the demand for currency, used as an indirect measure of shadow economic activity. This is likely due to a high degree of correlation between important variables combined with a relatively short time series. In future work it will be interesting to try other measures of the tax burden or extend the time period to see if one can better capture evidence of the demand for cash for use in the shadow economy.

We then turn to micro data from large-scale household surveys to study the level of underreporting by different types of households and how this level changes over time. Using a food consumption function we estimate how much income is needed to support a given level of consumption by a group of families that are believed to fully report their income and use this information to gauge by how much the true income needs to be above the reported income for households assumed to underreport income to support their reported consumption. We find that the level of underreporting of the latter group goes down in 2005, but then rebounds. Limitations of this approach include relying on unsupported assumptions about the behavior of the variables and discarding many interesting types of households.

Finally, we look at the consumption-income gap for households as a mechanism for capturing income underreporting by certain types of households. Given that consumption patterns show limited variation over time, changes in the size of this gap are mostly due to changes in reported income, which are in turn affected by the tax system. We find strong evidence indicating that the size of the gap decreased in the years following reform, even after we control for yearspecific changes. The biggest reduction in the gap occurs among households headed by a farmer, followed by households where the head does not report any working status. Employed and selfemployed households, on the other hand, appear to be very similar in their consumption income pattern before the tax reform and to have a similar reaction to the reform. Both groups show a minimal change in their consumption-income gap post-reform. 
In summary, the methods that make the best use of the limited available data suggest that while the flat tax reform in Georgia may have contributed to an increase in the extent of income reporting, this effect varies across employment types and may well be due to simultaneous increases in enforcement activities. 


\section{Appendix}

Table A1: Variable Summary Statistics, Method A

\begin{tabular}{|l|c|c|c|c|}
\hline \multicolumn{1}{|c|}{ Variable } & Mean & St. Dev. & Min & Max \\
\hline Currency in Circ. (Thousands of GEL) & 794.0 & 431.1 & 249.0 & 1618.2 \\
\hline GDP (Millions of GEL) & 3170.0 & 1376.7 & 1396.9 & 6374.5 \\
\hline Inflation (\%) & 6.4 & 3.0 & -0.8 & 13.0 \\
\hline Tax Burden (\% of GDP) & 10.8 & 3.2 & 5.3 & 17.5 \\
\hline Welfare spending (\% of GDP) & 5.7 & 1.9 & 1.9 & 9.6 \\
\hline Interest Rate & 8.2 & 1.6 & 5.6 & 11.6 \\
\hline Dollarization (\%) & 73.0 & 7.5 & 58.0 & 85.4 \\
\hline Number of observations & & 44 & \\
\hline
\end{tabular}

Currency in circulation is measured in current millions of GEL and is taken from "Money Aggregates and Monetary Ratios" data published by the National Bank of Georgia (NBG): http://nbg.ge/index.php?m=306.

We use GDP at market prices denominated in millions of current GEL. The data are from the National Statistics Office of Georgia, http://geostat.ge/index.php?action=page\&p id=119\&lang=eng

Our first best for option for data on tax/regulatory burden would be data on tax revenues and social contributions collected by the government. Unfortunately, consolidated budget of the government reported by the Ministry of Finance of Georgia that reports these two variables is only available from 2006-on (see http://www.mof.ge/StatisticBudget). So, our measure of tax burden relies on

1) data on taxes form products reported in GDP by categories of use. Source is the National Statistics Office of Georgia

(http://geostat.ge/index.php?action=page\&p_id=119\&lang=eng). We take the share of taxes for products over GDP is our first measure of tax burden.

2) In addition we measure the size of social contributions (welfare spending) by the government which is closely related to the collected social contributions (the correlation coefficient between the two is 0.8 for period 2000-2008. In 2008 the social tax was added to the income tax, so the line on collected social contributions becomes zero. If we had data on total tax, which includes income tax, it would pick up this change. Since we have to use tax on goods and services, we keep the size of government contributions that will continue capturing the portion of the tax burden that used to come from social tax). Data on social contributions have been requested from the Ministry of Finance. Hence, the share of welfare spending over GDP is used as our second measure of tax burden.

As our measure of inflation we use the Consumer Price Index, growth rate over the same period of previous year. The source of data is the UNECE (United Nations Economic Commission for Europe) database, in particular section on Economics Statistics, Price Indices by Country and Quarter (http://w3.unece.org/pxweb/?lang=1). We use short-term and long-term interest rates on commercial banks' deposits for national currency, for foreign currency, as well as for total currency (average weighted rates) reported by the NBG in "Interest Rates on Deposits, by quarters and years" file, http://nbg.ge/index.php?m=306.

Dollarization Ratio of Deposits included in Broad Money (in percentage) and Dollarization Ratio of the Total Non-Bank Deposits (in percentage) are from the NBG "Money Aggregates and Monetary Ratios" dataset: http://nbg.ge/index.php?m=306. 
Table A2: Unit Root Test Results, Method A

\begin{tabular}{|l|c|c|c|c|c|c|}
\hline \multicolumn{1}{|c|}{ Variable } & DF & PP & ZA & Break & Trend & Test Result \\
\hline Ln(Currency in Circ.) & -2.25 & -2.32 & -3.21 & $2008 \mathrm{Q1}$ & Yes & Unit Root \\
\hline Ln(GDP) & -4.84 & -4.85 & -5.514 & $2008 \mathrm{Q1}$ & Yes & No Unit Root \\
\hline Inflation & -2.56 & -2.70 & -4.7 & $2008 \mathrm{Q} 4$ & No & Unit Root \\
\hline Interest Rate & -1.57 & -1.66 & -2.51 & $2004 \mathrm{Q1}$ & Yes & Unit Root \\
\hline Ln(1+Tax Burden/100) & -1.72 & -1.55 & -3.00 & $2004 \mathrm{Q3}$ & No & Unit Root \\
\hline Ln(1+ Welfare sp./100) & -3.98 & -4.03 & -7.73 & $2007 \mathrm{Q} 4$ & No & No Unit Root \\
\hline Dollarization & -1.01 & -1.06 & -3.45 & $2008 \mathrm{Q} 4$ & No & Unit Root \\
\hline
\end{tabular}

Note: DF=Dickey-Fuller test, PP=Phillips-Perron test, ZA-Zivot-Andrews test for unit-root. The table reports test-statistics for each of the 3 listed tests. Column "Break" shows the time period in which the Zivot-Andrews test detects a structural break in time series. Column "Trend" indicates if each of the series has a deterministic time trend in it, based on preliminary tests.

Critical values for the tests are:

\begin{tabular}{|l|c|c|}
\hline Test: & $\mathbf{1 \%}$ Crit.Val. & $\mathbf{5 \%}$ Crit.Val \\
\hline DF and PP tests, 44 observations, no trend & -3.63 & -2.95 \\
\hline DF and PP tests, 44 observations, with trend & -4.21 & -3.53 \\
\hline ZA test, 44 observations, no trend & -5.43 & -4.80 \\
\hline ZA test, 44 observations, with trend & -4.93 & -4.42 \\
\hline
\end{tabular}


Figure A1. Zivot-Andrews Test Statistics, 2001q4-2009q1
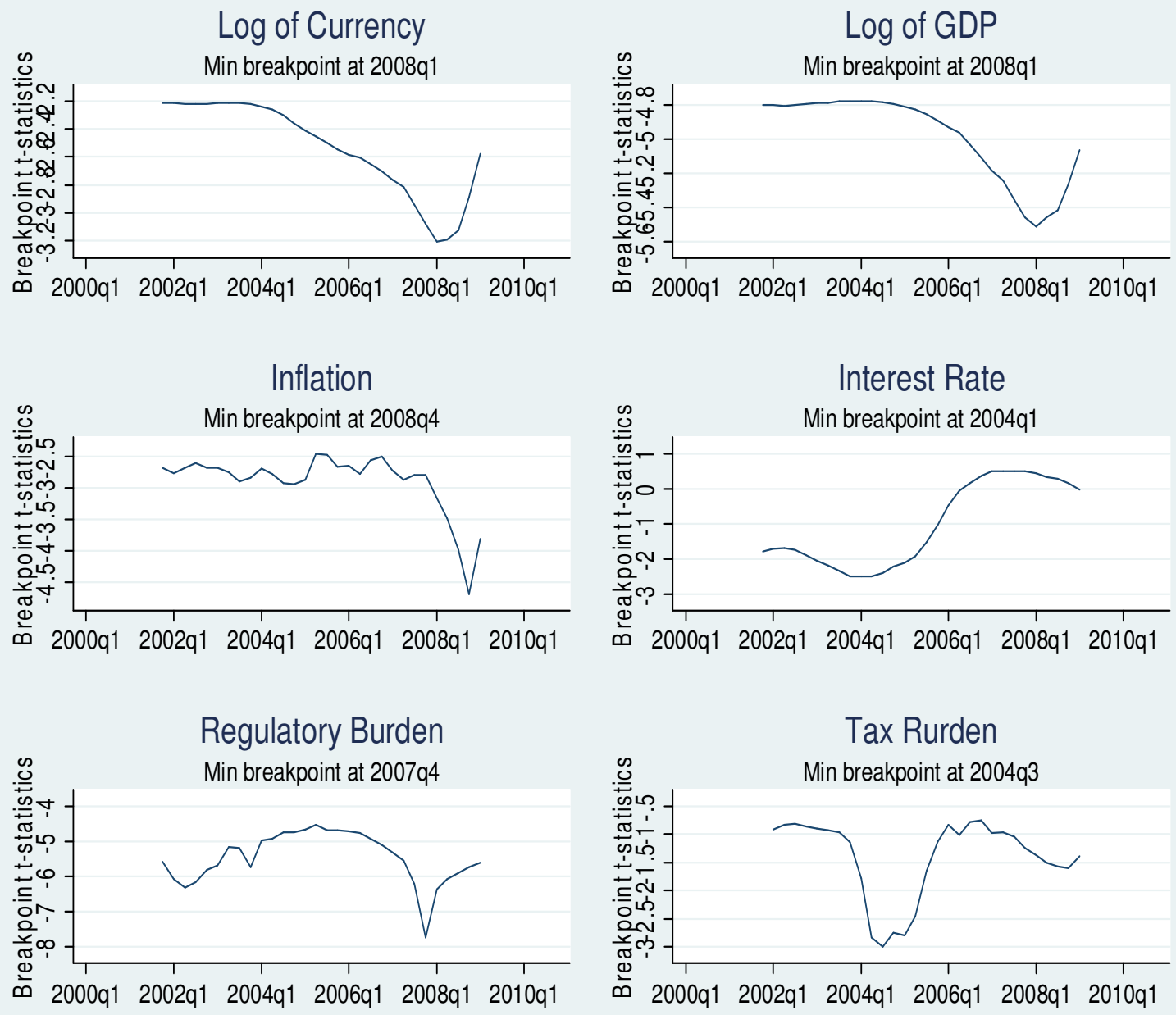

Table A3: Matrix of Variable Correlations, Method A

\begin{tabular}{|l|c|c|c|c|c|c|}
\hline & $\operatorname{In}($ GDP) & Inflation & Int. rate & Tax burd. & Welf. sp. & Dollar. \\
\hline In(GDP) & 1.00 & & & & & \\
\hline Inflation & 0.38 & 1.00 & & & & \\
\hline Int.rat & -0.36 & -0.54 & 1.00 & & & \\
\hline Tax burd. & 0.88 & 0.39 & -0.36 & 1.00 & & \\
\hline Welf. sp. & 0.54 & -0.12 & 0.17 & 0.50 & 1.00 & \\
\hline Dollarization & -0.79 & -0.50 & 0.22 & -0.87 & -0.43 & 1.00 \\
\hline
\end{tabular}


Table A4: Summary Statistics of Food Expenditure and Income by HH Types (constant 2005 GEL)

\begin{tabular}{|c|c|c|c|c|c|c|c|c|}
\hline \multirow{3}{*}{ Year } & \multicolumn{4}{|c|}{ Self-employed households $(\mathrm{N} \approx 450)$} & \multicolumn{4}{|c|}{ Employed households $(\mathrm{N} \approx 1200)$} \\
\hline & \multicolumn{2}{|c|}{$\begin{array}{l}\text { Monthly food } \\
\text { expenditure }\end{array}$} & \multicolumn{2}{|c|}{$\begin{array}{l}\text { Monthly } \\
\text { income }\end{array}$} & \multicolumn{2}{|c|}{$\begin{array}{l}\text { Monthly food } \\
\text { expenditure }\end{array}$} & \multicolumn{2}{|c|}{$\begin{array}{l}\text { Monthly } \\
\text { income }\end{array}$} \\
\hline & Mean & St dev & Mean & St dev & Mean & St dev & Mean & St dev \\
\hline 2003 & 134.8 & 105.6 & 207.3 & 191.1 & 144.9 & 114.3 & 202.2 & 198.0 \\
\hline 2004 & 154.5 & 120.7 & 218.9 & 188.7 & 149.1 & 108.0 & 213.7 & 222.0 \\
\hline 2005 & 130.2 & 109.6 & 197.4 & 146.7 & 147.1 & 103.8 & 250.8 & 221.4 \\
\hline 2006 & 133.0 & 94.1 & 218.8 & 187.0 & 142.7 & 101.1 & 286.0 & 297.0 \\
\hline 2007 & 135.2 & 90.3 & 228.0 & 173.0 & 147.0 & 103.5 & 318.6 & 318.4 \\
\hline
\end{tabular}

Table A5: Summary Statistics for Right-hand-side Variables, Method B

\begin{tabular}{|c|c|c|c|c|}
\hline Variables (x) & Mean & Std. Dev. & Min & Max \\
\hline Self-employed HH & 0.28 & 0.45 & 0 & 1 \\
\hline \multicolumn{5}{|l|}{ Head of HH characteristics } \\
\hline Male & 0.61 & 0.49 & 0 & 1 \\
\hline Married & 0.68 & 0.47 & 0 & 1 \\
\hline Elementary education & 0.01 & 0.11 & 0 & 1 \\
\hline Incomplete secondary educ. & 0.03 & 0.17 & 0 & 1 \\
\hline Vocational-technical educ. & 0.09 & 0.29 & 0 & 1 \\
\hline Special secondary educ. & 0.16 & 0.36 & 0 & 1 \\
\hline Higher education & 0.43 & 0.50 & 0 & 1 \\
\hline Age & 45.97 & 12.99 & 15 & 91 \\
\hline \multicolumn{5}{|l|}{ HH characteristics } \\
\hline Presence of disabled & 0.15 & 0.36 & 0 & 1 \\
\hline Number of old people & 0.48 & 0.70 & 0 & 4 \\
\hline Number of adults & 2.99 & 1.25 & 1 & 9 \\
\hline Number of kids, $0-5$ years old & 0.23 & 0.52 & 0 & 4 \\
\hline Number of kids 6-16 years old & 0.63 & 0.86 & 0 & 6 \\
\hline HH from urban area & 0.71 & 0.45 & 0 & 1 \\
\hline \multicolumn{5}{|l|}{ Variables (z) } \\
\hline Car ownership & 0.22 & 0.41 & 0 & 1 \\
\hline TV ownership & 0.89 & 0.31 & 0 & 1 \\
\hline $\begin{array}{r}\text { Partner of the head had a job in the last } \\
3 \text { months }\end{array}$ & 0.42 & 0.49 & 0 & 1 \\
\hline Partner of the head self-employed & 0.06 & 0.24 & 0 & 1 \\
\hline $\mathbf{N}$ & \multicolumn{4}{|c|}{825} \\
\hline
\end{tabular}


Table A6: Tests for Normality in Log of Income

\begin{tabular}{|c|c|c|c|c|c|c|}
\hline Test & \multicolumn{3}{|c|}{ Skewness/Kurtosis test } & \multicolumn{3}{c|}{ Shapiro-Francia test } \\
\hline Year & chi2(2) & Prob>chi2 & Result & $\mathbf{z}$ & Prob $>\mathbf{z}$ & Result \\
\hline $\mathbf{2 0 0 3}$ & 20.61 & 0.000 & Not Normal & 3.25 & 0.001 & Not Normal \\
\hline $\mathbf{2 0 0 4}$ & 43.09 & 0.000 & Not Normal & 4.63 & 0.000 & Not Normal \\
\hline $\mathbf{2 0 0 5}$ & 15.31 & 0.001 & Not Normal & 2.84 & 0.002 & Not Normal \\
\hline $\mathbf{2 0 0 6}$ & 19.82 & 0.000 & Not Normal & 3.38 & 0.000 & Not Normal \\
\hline $\mathbf{2 0 0 7}$ & 1.18 & 0.554 & Normal & 0.99 & 0.160 & Normal \\
\hline
\end{tabular}

Table A7: Tests for Group-wise Heteroscedasticity and Endogeneity, Method B

\begin{tabular}{|c|c|c|c|c|c|c|c|c|c|}
\hline Test & \multicolumn{2}{|c|}{ HS in (5) } & Test & \multicolumn{2}{c|}{ HS in (6) } & Test & Endog. of Y & Test \\
\cline { 1 - 1 } Year & F-stat & P>F & result & F-stat & P-val & result & F-stat & P-val & result \\
\hline $\mathbf{2 0 0 3}$ & 13.27 & 0.000 & HS & 1.17 & 0.279 & No HS & 1.31 & 0.253 & No En \\
\hline $\mathbf{2 0 0 4}$ & 3.79 & 0.052 & HS & 0.01 & 0.912 & No HS & 1.90 & 0.168 & No En \\
\hline $\mathbf{2 0 0 5}$ & 0.04 & 0.836 & No HS & 10.13 & 0.001 & HS & 0.44 & 0.509 & No En \\
\hline $\mathbf{2 0 0 6}$ & 0.03 & 0.859 & No HS & 3.79 & 0.051 & HS & 2.84 & 0.092 & En \\
\hline $\mathbf{2 0 0 7}$ & 0.98 & 0.322 & No HS & 1.64 & 0.200 & No HS & 6.01 & 0.014 & En \\
\hline
\end{tabular}


Table A8: Summary Statistics for Variables, Method C

\begin{tabular}{|c|c|c|c|c|}
\hline Variables & Mean & Std. Dev. & Min & Max \\
\hline \multicolumn{5}{|l|}{ Head of HH characteristics } \\
\hline Male & 0.55 & 0.50 & 0 & 1 \\
\hline Married & 0.56 & 0.50 & 0 & 1 \\
\hline Elementary education & 0.06 & 0.24 & 0 & 1 \\
\hline Incomplete secondary educ. & 0.08 & 0.27 & 0 & 1 \\
\hline Vocational-technical educ. & 0.08 & 0.26 & 0 & 1 \\
\hline Special secondary educ. & 0.14 & 0.34 & 0 & 1 \\
\hline Higher education & 0.33 & 0.47 & 0 & 1 \\
\hline Age & 54.71 & 17.27 & 15 & 106 \\
\hline Had job in the last 7 days & 0.63 & 0.48 & 0 & 1 \\
\hline Had contractual job & 0.41 & 0.49 & 0 & 1 \\
\hline Was self-employed & 0.14 & 0.35 & 0 & 1 \\
\hline Was a farmer & 0.13 & 0.33 & 0 & 1 \\
\hline Had a non-paid job & 0.02 & 0.12 & 0 & 1 \\
\hline \multicolumn{5}{|l|}{ HH characteristics } \\
\hline Presence of disabled & 0.17 & 0.37 & 0 & 1 \\
\hline Number of old people & 0.67 & 0.75 & 0 & 4 \\
\hline Number of members & 3.26 & 1.81 & 1 & 14 \\
\hline Number of kids, 0-5 years old & 0.17 & 0.46 & 0 & 4 \\
\hline Number of kids 6-16 years old & 0.48 & 0.80 & 0 & 6 \\
\hline HH from urban area (excl. Tbilisi) & 0.31 & 0.46 & 0 & 1 \\
\hline HH from Tbilisi & 0.29 & 0.45 & 0 & 1 \\
\hline Number of members with primary ed & 0.11 & 0.38 & 0 & 5 \\
\hline 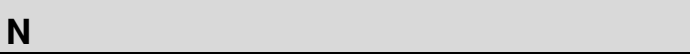 & \multicolumn{4}{|c|}{14481} \\
\hline
\end{tabular}




\section{Definitions of various consumption and income variables used in text}

Below are household consumption categories reported in the Georgian household survey:

a) Expenditure on food consumed in and outside the household; reported in weekly diary of expenses, multiplied by $30 / 7$ to estimate monthly equivalent.

b) Expenditure on non-food items, reported monthly for the last 3 month preceding the survey. This category includes items such as rent, house repairs, payment of utilities, cost of fuel, communication expenditures, expenditures on textiles, tableware, toiletry, car maintenance costs, shipment, transportation, healthcare, education expenditures, entertainment, and recreation. For the calculation of consumption we include the average of these expenditure categories for 3 months, to smooth some short-term fluctuations.

c) Remittances sent to others; reported on quarterly bases. The amount is divided by 3 for aggregation into monthly expenditures.

d) Debt repayment, savings, and lending during the last 3 months. The amount is divided in 3 to get to monthly values.

e) Gifts and money given away, reported monthly for the last 3 months. We take the average of the last 3 months for smoothing.

f) Expenditure on durables, reported quarterly. We use $1 / 3$ of this amount in aggregation.

Based on these categories of expenditures and following Gorodnichenko (2009) we define the following types of aggregated consumption expenditure:

C1 - expenditure on food, non-food items, utilities, and various types of services (categories $a$ and $b$ )

C2 - extended definition of consumption that includes $\mathrm{C} 1$ plus payments to others by household members (including expenditures listed in categories $c, d$ and e)

$\mathrm{C} 3$ - consumption $\mathrm{C} 1$ plus purchases of durable goods (category $\mathrm{f}$ )

These are household income sources reported in the survey:

a) Monthly income ${ }^{17}$ from employment: regular contractual payments for contracted workers, income from self-employment, bonus and other non-regular payments; reported for the last 3 months from the date of the interview.

\footnotetext{
${ }^{17}$ The survey asks for gross as well as net amounts, however data are almost identical for net and gross columns or is simply missing in one of them
} 
b) Monthly income from social transfers (social aid, pensions, government grants and scholarships, disability and unemployment payments, etc.);reported for the last 3 months from the date of the interview.

c) Income from sale of property, inheritance of property, late payments for work conducted earlier or property given away earlier; reported on quarterly bases (when aggregating these amounts into monthly household income we take $1 / 3$ of reported amounts).

d) Income received as gifts for special events (i.e. weddings, birthdays, etc.);reported for the last 3 months from the date of the interview.

e) Income from remittances; reported on quarterly bases (when aggregating these amounts into monthly household income we take $1 / 3$ of reported amounts).

f) Monthly revenue (in GEL) from selling harvest, home-made products, animals, animal products, home-made animal products; reported for the last 3 months from the date of the interview.

Alternative definitions of aggregate income that we use in the paper include:

Y1 -regular portion of labor and non-labor income, income from social transfers (categories $\mathrm{a}$ and $\mathrm{b}$ and part of $\mathrm{c}$ )

$Y 2-Y 1$ plus income from irregular sources (remaining part of $c$, and categories $d$ and e)

$\mathrm{Y} 3-\mathrm{Y} 1$ plus revenues from farming activities (category $\mathrm{f}$ )

All income and consumption variables are converted to 2005 Q1 price level using Georgian quarterly CPI series from the National Bank of Georgia. 


\section{References:}

Ahumada, Hildegart; Alvaredo, Facundo and Canavese Alfredo (2006) "The Demand for Currency Approach and The size of Shadow Economy: A Critical Assessment", Berkeley program in Law and Economics Working Paper Series

Allingham, Michael and Sandmo, Agnar (1972) "Income Tax Evasion: A Theoretical Analysis," Journal of Public Economics 1(3): 323-338.

Bajada Christopher and Schneider Friedrich (2005) "The Shadow Economies of the Asia-Pacific" Pacific Economic Review 10: 3

Breusch, T. (2005a) "Australia's Cash Economy: Are the estimates credible?," The Australian National University, mimeo.

Breusch, T. (2005b) "Fragility of Tanzi's method of estimating the underground economy," The Australian National University, mimeo.

Cagan, Phillip (1958) "The Demand for Currency Relative to the Total Money Supply," Journal of Political Economy, 66(3): 302-328.

Caridi, P. and Passerini, P. (2001) "The Underground Economy, the Demand for Currency Approach and the Analysis of 18Discrepancies: Some Recent European Experience, Review of Income and Wealth, 47:2.

Cebula, Richard J. (1997) "An Empirical Analysis of the impact of Government Tax and Auditing Policies on the Size of the Underground Economy: The Case of the United States," American Journal of Economics and Sociology, 56(2): 173-185.

Cowell, Frank A. (1985) "Tax Evasion with Labor Income," Journal of Public Economics, 26(1): 1935.

European Commission (2007) "Undeclared Work in the European Union." Special Eurobarometer, 284.

Feige, E. (1979) "How Big is the Irregular Economy?"; Challenge, 22:1.

Friedman, Eric; Johnson, Simon; Kaufmann, Daniel and Zoido-Lobaton, Pablo (2000) "Dodging the Grabbing Hand: The Determinants of Unofficial Activity in 69 Countries," Journal of Public Economics 76(3): 459-493.

Giles, David E. A. and Johnson, Betty J. (2002) "Taxes, Risk-Aversion, and the Size of the Underground Economy: A Nonparametric Analysis with New Zealand Data," Pacific Economic Review, 7(1): 97-113,

Gorodnichenko, Yuriy; Martinez-Vazquez, Jorge; Sabirianova, Klara P. (2009) "Myth and Reality of Flat Tax Reform: Micro Estimates of Tax Evasion Response and Welfare Effects in Russia," Journal of Political Economy, 117(3): 504-554,

Gutmann, P. (1977) “The Subterranean Economy”; Financial Analysts Journal, 34:1. 
Hill, Roderick and Kabir, Muhammed (1996) "Tax Rates, the Tax Mix and the Growth of the Underground Economy in Canada: What Can We Infer?" Canadian Tax Journal, 44(6): $1552-1583$.

Keen, Michael, Kim, Titae and Varsano, Ricardo (2006) "The 'Flat Tax(es)': Principles and Evidence. Washington, D.C.: IMF Working Paper WP/06/218.

KessIman, Jonathan R. (1989) "Income Tax Evasion: An Intersectoral Analysis," Journal of Public Economics, 38(2): 137-182.

Kolm, Ann-Sofie, and Nielson, Søren Bo (2008) "Under-reporting of income and labor market performance." Journal of Public Economic Theory, 10(2): 195-217.

Koskela, Erkki (1983) "A Note of Progression, Penalty Schemes and Tax Evasion," Journal of Public Economics, 22(1): 122-133.

Lacroix, Guy and Fortin, Bernard (1992) "Utility-Based Estimation of Labour Supply Functions in the Regular and Irregular Sectors," Economic Journal, 102(415): 1407-1422.

Lyssiotou, Panayiotou, Pashardes, Panos and Stengos, Thanasis (2004) "Estimates of the Black Economy Based on Consumer Demand Approaches," The Economic Journal, 114(497): 622-640.

Pencavel, John H. (1979) "A Note on Income Tax Evasion, Labor Supply, and Nonlinear Tax Schedules," Journal of Public Economics, 12(1): 115-124.

Perron, Pierre (1989) "The Great Crash, the Oil Price Shock, and the Unit Root Hypothesis" Econometrica, 57(6): 1361-1401.

Pissarides, Christopher A. and Guglielmo Weber (1989) "An expenditure-based estimate of Britain's black economy," Journal of Public Economics, 39(1):17-32

Schneider, Friedrich, Buehn, Andreas and Montenegro, Claudio (2010) "Shadow Economies all over the World: New Estimates for 162 Countries from 1999 to 2007", The World Bank Policy Research Working Paper Series, working paper 5356.

Schneider, Friedrich (2004) "The Size of the Shadow Economies of 145 Countries All Over the World: First Results Over the Period 1999 to 2003," Bonn: IZA Discussion paper No. 1431.

Schneider, Friedrich, and Dominik Enste (2002) "The Shadow Economy: An International Survey", Cambridge (UK): Cambridge University Press.

Slonimczyk, Fabián (2011) "The Effect of Taxation on Informal Empoloyment: Evidence from the Russian Flat Tax Reform,” Moscow: Higher School of Economics, mimeo.

Tanzi, Vito (1983) "The Underground Economy in the United States: Annual Estimates, 19301980," International Monetary Fund Staff Papers, 33(4): 799-811.

Tedds, Lindsay M. (2006) "Nonparametric Expenditure-Based Estimates of Income UnderReporting and the Underground Economy," Winnipeg: University of Manitoba (http://home.cc.umanitoba.ca/ tedds/Nonparm\%20estimation\%20of\%20income\%20underr eporting\%20-\%20April\%202006.pdf) 
Thiessen, Ulrich (2003) "The Impact of Fiscal Policy and Deregulation on Shadow Economies in Transition Countries: The Case of Ukraine," Public Choice, 114(3-4): 295-318.

Trandel, Greg and Snow, Arthur (1998) "Progressive Income Taxation and the Underground Economy," Economics Letters 62(2): 217-222.

Watson, Harry (1985) "Tax Evasion and Labor Markets," Journal of Public Economics, 27(2): 231246.

World Bank (2012) Fighting Corruption in Public Services: Chronicling Georgia's Reforms, Washington, D.C.: The World Bank.

Yitzhaki, Schlomo (1974) "A Note on 'Income Tax Evasion: A Theoretical Analysis'," Journal fo Public Economics, 3(2): 201-202.

Zivot, Eric, and Donald Andrews (2002) "Further Evidence on the Great Crash, the Oil-Price Shock, and the Unit-Root Hypothesis", Journal of Business and Economic Statistics, 20(1), 25-44. 